Our Nature (2009) 7:218-221

\title{
Studies on Length-weight and Length-length Relationship of a Freshwater Fish Gudusia godanahiae from Biratnagar, Nepal
}

\author{
B.R. Subba ${ }^{1 *}$, R.K. Bhagat ${ }^{2}$ and S. Adhikaree ${ }^{1}$ \\ ${ }^{1}$ Department of Zoology, P.G. Campus, Tribhuvan University, Biratnagar \\ ${ }^{2}$ Department of Zoology, MMAM Campus, Tribhuvan University, Biratnagar \\ "E-mail:subbabharat@yahoo.com
}

Received: 21.11.2009, Accepted: 20.12.2009

\begin{abstract}
Present study describes the length-weight (LWR) and length-length (LLR) relationships of a freshwater fish Gudusia godanahiae from a fish pond of Sarochiya, Biratnagar, Nepal. 91 specimens of G. godanahiae were collected from fisherman's catch from Nov 2008 to Oct 2009, were used for this study. The slope value (b) of the LWR are not so close to isometric growth, $(b=2.9017)$. Results for LLR $\left(r^{2}>0.9\right) \quad \mathrm{P}<0.001$ indicate that these are highly corrected and highly significant.
\end{abstract}

Key words: Gudusia godanahiae, length-weight, length-length, relationship

\section{Introduction}

The study of the length weight relationship of fishes is of vital importance to the fishery biologists, in setting up yield equations in the study of population dynamics, taxonomic differences, events in life history like metaporphosis, maturity (Le Cren, 1951), in determining the pattern of growth of stock and to the fisheries officials in evolving effective policies for the management and conservation. In fishes, generally the growth pattern follows the Cube law (Brody, 1945; Lagler, 1952) but the actual relationship may depart from this (Le Cren, 1951) either due to environmental factors or condition of fish. The mathematical relationship between length and weight of fishes is a practical index suitable for understanding their survival, growth, maturity, reproduction and general well being (Le Cren, 1951)
The relationship is generally expressed by the equation: $\mathrm{W}=\mathrm{a} \mathrm{L}^{\mathrm{b}}$. Several workers viz. Mohammed (1956), Jhingran (1959), Sinha (1973), Pandey et al. (1974), Pathak (1975), Kumar et al. (1979), Subba and Ghosh (2000), Subba and Pandey (2000), Dhakal and Subba (2003), Soomro et. al., (2007), Ansumala and Subba (2009) have been used this equation in different fish species obtained from different environmental condition.

Length-weight relationship are useful in fishery management for both applied and basic use (Pitcher and Hart, 1982) to (i) estimate weight from length observations; (ii) calculate production and biomass of fish population; and/or (iii) provide information on stock or organism condition at the corporal level. Length-length relationships (LLR) are also important in fisheries 
management for comparative growth studies (Moutopoulos and Stergiou, 2002). Present work will provide baseline information for the growth of the fish Gudusia godanahiae on the basis of the length-weight and lengthlength relationship study.

\section{Materials and methods}

A total 91 specimens were collected from a local fish pond located at Sarochiya, Biratnagar, Nepal, from Nov. 2008 to Oct. 2009. Total length (TL) and fork length (FL) were measured using a divider and a scale $(\mathrm{mm})$, while weight was determined as total weight (Wt) including gut and gonads, using a digital balance to the nearest $1 / 100 \mathrm{gm}$. The specimens ranged from 1 to $34.8 \mathrm{~g}$ in weight and 47 to $167 \mathrm{~mm}$ in total length. The values of constants $a$ and $b$ were estimated from the $\log$ transformed values of length and weight i.e. $\log W=\log a$ $+b \log L$, via least square linear regression (Zar, 1984). The coefficient $a$ is the intercept, and the regression of coefficient $b$ is an exponent, indicating isometric growth when equal to 3.0, a value larger or smaller than 3.0 shows allometric growth (Bagenal and Tesch, 1978). Furthermore, relationships in between FL v/s TL were also estimated by using the above least square linear regression equation. Relationship equations were established by least square method. Logarithmic transformations of the data were used for length-weight relationships.

\section{Results and discussion}

The body weight of Gudusia godanahiae showed a clear cut increasing trend with the increase in body length. When the logarithmic values of weight were plotted on the co-ordinate (Y-axis) against those of respective length on the abscissa (X-axis) they always gave straight lines in all cases as shown in figures $1 \mathrm{a}, \mathrm{b}, 3$ and 4 .

Regression equations for all forms (combined data) are as follows:

For length-length:

$\mathrm{TL}=1.228 \mathrm{FL}+0.1349$

or $\mathrm{FL}=0.7995 \mathrm{TL}-0.0432$

For length-weight:

$\mathrm{Wt}=0.0104 \mathrm{TL}^{2.9017}$

or Log Wt $=2.9017 \log \mathrm{TL}-1.9818$

$\mathrm{WT}=0.0213 \mathrm{FL}^{2.863}$

or Log Wt $=2.863 \log$ FL -1.6709

The exponent $b$ values for the total length and weight is 2.9017 and that of forcal length and weight is 2.863. The values of regression coefficient (b) for all length-weight relationship came close to be 3. The $b$ values show negative allometric growth. The value of ' $b$ ' is higher in the case of total length-weight relation than that of forcal length-weight relation. Results for LLR indicate that these are highly correlated $r^{2}>0.9$ i.e. $\mathrm{P}<0.001$.

All allometric coefficients (b) estimated in this study were within the expected range 2.5-3.5. According to Pauly and Gayanilo (1997), $b$ values may range from 2.5 to 3.5 suggesting that the result of this study is valid. The value for correlation coefficient $\left(r^{2}\right)$ for the length-length parameter was $>0.9$, hence it is highly significant $(\mathrm{P}<0.001)$. In the case of lengthlength (Forcal length and total length) relationship, exponent ' $b$ ' values are -0.0075 
B.R. Subba, R.K. Bhagat and S. Adhikaree / Our Nature (2009) 7: 218-221

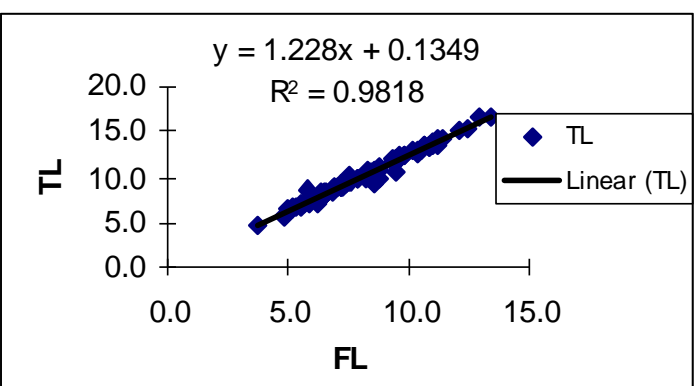

a

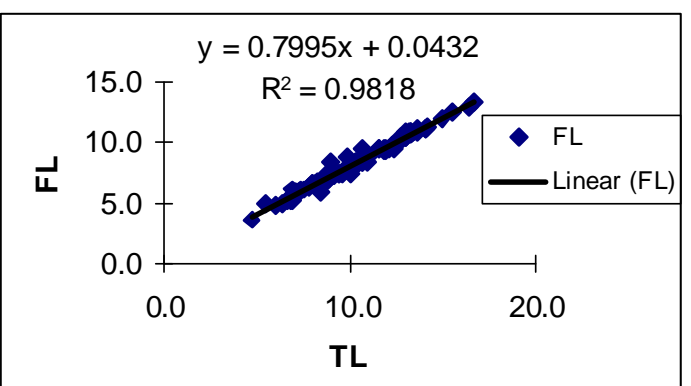

b

Figure 1. Graphs with regression equation and coefficient of determination $\left(\mathrm{r}^{2}\right)$ for all specimens showing lengthlength relation (a) $\mathrm{TL}=1.228 \mathrm{FL}+0.1349$ (b) $\mathrm{FL}=0.7995 \mathrm{TL}-0.0432$

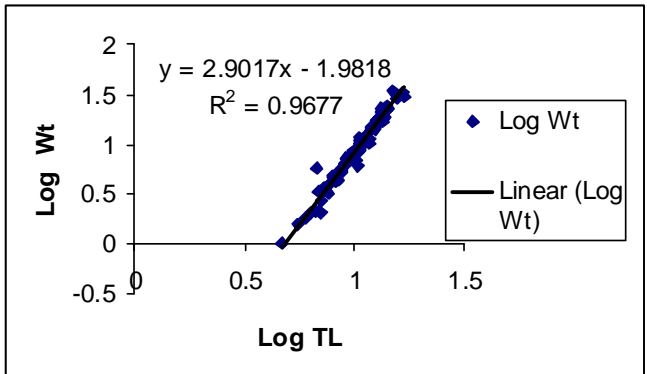

Figure 2. Graphs with regression equation and coefficient of determination $\left(\mathrm{r}^{2}\right)$ for all specimens

and 0.2207 the former reveals that forcal length is nearly $80 \%$ of the total length, whereas, the latter indicates that the total length is a little bit more than $120 \%$ of the forcal length.

The present study provides baseline information on LWR and LLR for Gudusia godanahiae. It will be useful for researchers and fishery managers.

The correlation coefficients (Figs. 1 a, b, 2, 3) in both cases are highly significant $(\mathrm{p}<0.001)$.

\section{Acknowledgements}

Authors would like to acknowledge fishermen who did not neglect to inform us in the time of fishing.

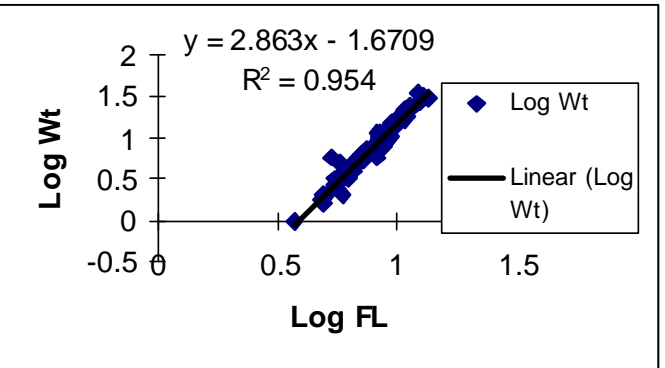

Figure 3. Graphs with regression equation and coefficient of determination $\left(r^{2}\right)$ for all specimens showing length-weight relation WT $=0.0213 \mathrm{FL}^{2.863}$ or $\log \mathrm{Wt}=2.863 \log \mathrm{FL}-1.6709$

\section{References}

Ansumala, A. and B.R. Subba 2009. Studies on length-weight relationship of a hillstream loach, Schistura rupicola (McClelland). J. Nat. Hist. Mus. 24: 126-129.

Begenal, T. and F.W. Tesch 1978. Age and Growth. Method for assessment of fish production in freshwater. (Ed. T. Bagenal), IBP Hand book, Blackwell Scientific Press, Oxford.

Brody, S. 1945. Bioenergetivs and Growth. Reinhold Publishing Corporation, New York. 1023p.

Dhakal, A and B.R. Subba 2003. Length-weight relationship of Lepidocephalichthys guntea of Pathri Khola Morang District. Our Nature 1: 53-57.

Hossain, M.Y., Z.F. Ahmed, P.M. Leunda, S. Jasmine, J. Oscoz, R. Miranda and J. Ohtomi 2006. Condition, length-weight and length-length relationship of the Asian striped catfish Mystus vittatus (Bloch, 1794) (Siluriformes: Bagridae) in the Mathbhang River, southwestern Bangladesh. $J$. Appl. Ichthyol. 22: 304-307. 
B.R. Subba, R.K. Bhagat and S. Adhikaree / Our Nature (2009) 7: 218-221

Jhingran, V.G. 1959. Studies on the age and growth of Cirrhina mrigala (Ham.) from the river Ganga. Proc. Nat. Inst. Sci. India. 25B(3): 107-137.

Kumar, K., L.K. Sehgal and S. Sunder 1979. Lengthweight relationship and ponderal index of brown trout, Salmotrutta fario (Linn.) catches in the streams of Kashmir. J. Inland Fish. Soc., India. 11(1): 56-61.

Lagler, K.F. 1952. Freshwater fishery biology. W.M.C. Brown Company, Dubyque. Iowa.

Le Cren, E.D. 1951. The length-weight relationships and seasonal cycle in gonad weight and condition in the perch (Perca fluviatilis). J. Anim. Ecol. 20: 201-219.

Mohamed, K.H. 1956. Preliminary observations on the biology and fisheries of the thread-fin Polyductylus indicus, shaw in the Bombay and Saurashtra waters. Indian J. Fish. 2(1): 164-179.

Moutopoulos, D.K. and K.I. Stergiou 2002. Lengthweight and length-length relationships of fish species from Aegean Sea (Greece). J. Appl. Ichthyol. 18: 200-2003.

Pathak, S.C. 1975. Length-weight relationship, condition factor and food study of Labeo calbasu (Ham.) from Loni reservoir (M.P.). J. Inland Fish. Soc., India. 8: 58-64.

Pauly, D. and Jr. F.C. Gayanilo 1997. A Bee: An alternatie approach to estimating the parameters of a length-weight relationship from length frequency samples and their bulk weights. NAGA ICLARM, Manila, Philippines.

Pitcher, T.J. and P.J. Hart 1982. Fisheries Ecology. Chapman and Hall, London.

Quadri, M.Y. and S. Mir 1980. Length-Weight relationship of Oreinus plagiio-stomus (McCL.). Geobios 7: 158-159.

Rao, G.R.M. and L.H.M. Rao 1972. On the biology of Labeo calbasu (Ham.) from the river Godaavari. $J$. Inland Fish. Soc., India. 4: 74-86.

Sinha, A.L. 1973. Length-weight relationship of a freshwater catfish, Clarias batrachus (Linn.). Ind. J. Zoot. 14(2): 97-102.

Soomro, A.N., W.A. Baloch, S.I.H. Jafri and H. Sujuki 2007. studies on length-weight and lengthlength relationships of catfish, Eutropichthyes vacha Hamilton (Schibeidae: Siluriformes) from Indus river, Sindh, Pakistan. Caspian J. Env. Sci. 5(2): 134-135.

Subba, B.R. and M.R. Pandey 2000. Length-weight relationship of Botia lohachata (Chand) from the Saptakoshi river, Nepal. J. Nat. His. Mus. 19: 8387.

Subba, B.R. and T.K. Ghosh 2000. Length-weight relationship of a hill-stream fish Glyptothorax telchitta (Ham.) from Saptakoshi river of Nepal. J. Indian Fish. Assoc. 27: 79-82.

Zar, J.H. 1984. Biostatistical analysis. Prentice Hall, New Jersey. 718 p. 